\title{
Upstream passage problems for wild Atlantic salmon (Salmo salar L.) in a regulated river and its effect on the population
}

\author{
H. Lundqvist · P. Rivinoja $\cdot$ K. Leonardsson • \\ S. McKinnell
}

(C) The Author(s) 2008

\begin{abstract}
Due to hydropower development, the upstream migration of wild anadromous salmon and brown trout is impaired in many European rivers, causing negative effects on the long-term survival of natural salmonid populations. This study identified problems for Atlantic salmon during upstream migration in a regulated river in northern Sweden, Umeälven (mean flow: $430 \mathrm{~m}^{3} \mathrm{~s}^{-1}$ ). Tagging from 1995 to 2005 involved radio tags $(n=503)$, PIT tags $(n=1574)$ and Carlin tags $(n=573)$ to study the spawning migration of salmon from the coast past the regulated section of the river to a fish ladder at the dam/spillway $32 \mathrm{~km}$ upriver. The results demonstrate that migration success from the coast to the fish ladder varied between $0 \%$ and $47 \%$ among years, indicating an average loss of
\end{abstract}

Guest editors: S. Dufour, E. Prévost, E. Rochard \& P. Williot Fish and diadromy in Europe (ecology, management, conservation)

H. Lundqvist $(\varangle) \cdot$ P. Rivinoja $\cdot$ K. Leonardsson Department of Wildlife, Fish, and Environmental Studies, SLU (Swedish University of Agricultural Sciences), Umeå 901 83, Sweden

e-mail: hans.lundqvist@vfm.slu.se

K. Leonardsson

Department of Ecology and Environmental Science, Umeå University, Umeå 901 87, Sweden

S. McKinnell

North Pacific Marine Science Organization, P. O. Box 6000, Sidney, BC, Canada V8L 4B2
$70 \%$ of potential spawners. Discharge from the turbines attracted the salmon away from the bypass route. Echo-sounding in the turbine outlet showed that salmon were normally found at 1-4 m depths. They responded with upstream and/or downstream movements depending on flow changes; increased spill in the bypass channel attracted salmon to the bypass. Once in the bypass channel, salmon could be delayed and had difficulties passing the first rapid at high spills. Additional hindrances to upstream migration were found at rapids and the area of the fish ladder, located further upstream in the regulated river section. The average migration duration was 44 days from the estuary to the top of the fish ladder, with large variation among individuals within years. Modelling the salmon population dynamics showed a potential population increase of $500 \%$ in 10 years if the overall migration success could be improved from the current $30 \%$ to levels near $75 \%$. Consequently improved migration facilities at the regulated river section should be implemented to achieve a long-term sustainability of these threatened anadromous salmonids.

Keywords Hydropower station - Tag - Migration success - Bypass channel · Fish ladder · Population model

\section{Introduction}

Natural salmonid populations have been eliminated or substantially reduced in many regulated rivers 
(Eriksson \& Eriksson, 1993; NRC, 1996). In a regulated river where water is diverted to turbines, changes to the natural flow of the river affect the fish migration. Consequently, problems can arise for adult fish on their way to spawning areas (Arnekleiv \& Kraabøl, 1996; Rivinoja et al., 2001; Karppinen et al., 2002). Furthermore, turbines and dams cause elevated mortalities for downstream migrating smolts (Montén, 1985; Coutant \& Whitney, 2000) and kelts (Scruton et al., 2002). Even if various fishways and guidance devices are constructed to maintain migration possibilities (Clay, 1995), their ability to attract and permit rapid and safe passage of fish (Katopodis, 1990) varies considerably. Upstream migrants can encounter problems in flow-controlled areas where they must find a way past turbine outlets to bypass channels where water volumes are relatively low compared to the main river (Arnekleiv \& Kraabøl, 1996; Quinn et al., 1997; Thorstad et al., 2003). Similarly, large variations in river flow or intermittent spills from dams can hinder the upstream migration (Rivinoja et al., 2001). Problems can also arise in the vicinity of fish ladders, where ladder attraction and passage flows might be ineffective in ensuring high success at upstream migration (Bjornn \& Peery, 1992). At the same time, environmental factors such as discharge volume and water temperature can affect the migration of fish in complex ways (Banks, 1969; Northcote, 1998). Discharge is one of the most important factors for attracting upstream migrants to the entrances of fishways, while adequate flows and water velocity within the fishway then secure upstream passage (Larinier, 1998; Williams, 1998).

In this paper, the results obtained from a ten-year study of adult Atlantic salmon (Salmo salar L.) passing through the flow regulated lower part of the River Umeälven are summarised. The migration behaviour of salmon at various obstacles in the regulated river is described with a focus on the migratory performance at different flows. A population model was used to estimate the consequences of improved escapements to the spawning grounds. Since anthropogenic impacts such as river regulation tend to diminish anadromous fish abundance, we highlight the long-term solutions to these migration problems so that viable populations can be maintained in future. Our results can be applied to other regulated river systems where bypasses are used to provide a migratory route for salmonids.

\section{Materials and methods}

Salmon and the River Umeälven study area

The rivers Umeälven and Vindelälven originate in parallel valleys with their headwaters in the mountains close to the Norwegian border, c. $450 \mathrm{~km}$ from the Bothnian Bay (Fig. 1). The Umeälven is dammed for hydroelectric power production throughout its length, so the passage of anadromous fish in this river is blocked by the first dam, Stornorrfors. The Vindelälven merges with the Umeälven $12 \mathrm{~km}$ above $\left(64^{\circ} \mathrm{N}\right.$,
Fig. 1 The regulated area that upstream migrating fish meet in the River Umeälven is the confluence of the turbine outlet and the bypass channel. Archival receivers, their location (open circles with numbers) and main reading transects (black arrows) were positioned for observation of individually radio-tagged salmon. From 1995 to 2003 the first archival receiver was situated in Umeå (1). The echo-sounding area at the turbine outlet is indicated by the white arrow

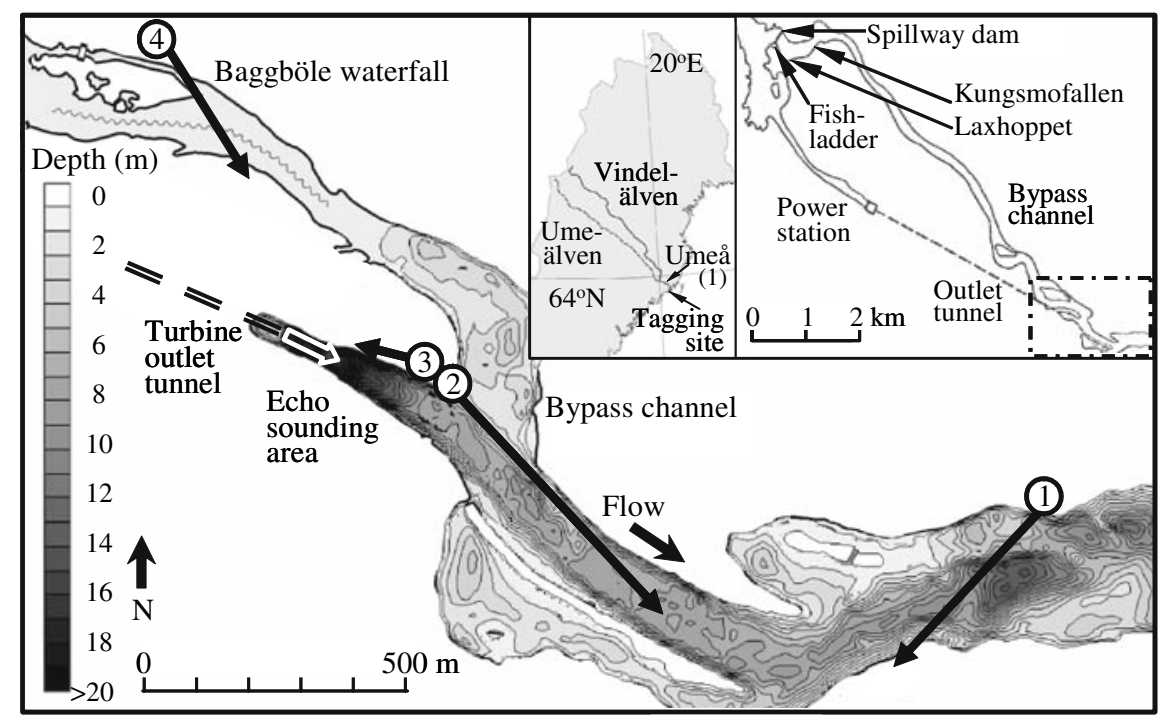


$20^{\circ}$ E) Stornorrfors. Anadromous Atlantic salmon and brown trout (Salmo trutta L.) gain access to the Vindelälven by way of a fish ladder at Stornorrfors, located $32 \mathrm{~km}$ upstream from the coast (Fig. 1). A hatchery immediately below the dam attempts to compensate for lost production of wild fish from the Umeälven by annually releasing c. 80,000 salmon and 20,000 sea trout smolts with their adipose fin removed to distinguish them from wild fish. At the top of the ladder, all migrating fish are trapped, counted, weighed, sexed and identified as either of wild (adipose fin intact) or hatchery origin (adipose fin removed). About $70 \%$ of the salmon at the ladder is of wild origin. These fish are released above the dam to continue their migration upstream to spawning areas in Vindelälven. Total annual counts have varied from 250 to 6065 salmon between 1974 and 2005, totalling 52,671 over the years (Fig. 2).

Migrating wild salmon in this river system generally enter the coastal areas in May and after holding for a period of time, start their upriver migration in June. In this report, upstream migrants are those adult salmon that ascended the river as far as the confluence area where turbine discharge mixes with water in the river, the first migration obstacle in the part of the river that is regulated (described below). In total, the river rises about $75 \mathrm{~m}$ from the sea level to the top of the fish ladder. To successfully reach to natural spawning areas in River Vindelälven, the salmon must pass the following sections of the regulated river (Fig. 1):

(1) The lower section of the river which has slowflowing water and extends from the coast up to the city of Umeå. The movements of radiotagged salmon in the uppermost part of this section were covered with an automatic receiver, located 17-21 km upstream from the coast.

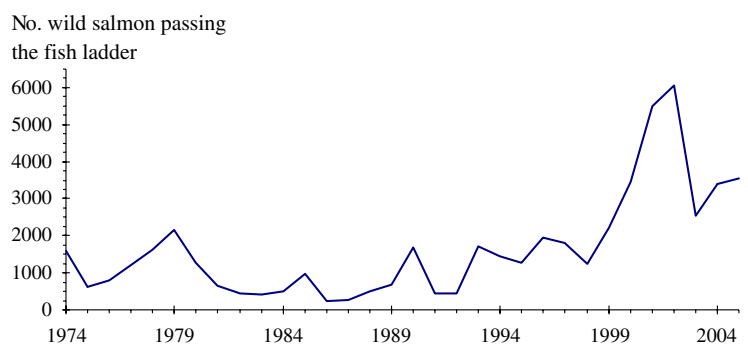

Fig. 2 Annual numbers of wild salmon, from 1974 to 2005, released past the fish ladder in River Umeälven to continue spawning migration to River Vindelälven $(n=52,671)$
(2) The middle section includes the confluence area. This section has relatively homogeneous fast-flowing water that extends from the first receiver in the lower section up to the confluence of the turbine discharge and the natural riverbed that is used as a bypass channel, 22-23 km upriver. The turbine outlet features a 250-m long, 20-40-m deep channel at the end of the submerged turbine tunnel.

(3) The bypass channel is $8 \mathrm{~km}$ in length with a total fall of $70 \mathrm{~m}$, and includes rapids and the fish ladder. The first rapid, Baggböle (height of $7.0 \mathrm{~m}$ ), is located $1 \mathrm{~km}$ upstream of the entrance to the bypass. The next impediments, in upstream order, are N. Kungsmofallet (height of $2.5 \mathrm{~m}$ ), then Ö. Kungsmofallet (height of $5.4 \mathrm{~m}$ ) and finally Laxhoppet (height of c. $4.2 \mathrm{~m}$ ), located $29-31 \mathrm{~km}$ from the coast. The fish ladder at the base of the dam (the location of a second receiver) is $240 \mathrm{~m}$ long, constructed of 65 ascending pools with associated weirs and orifices and has a total climb of $18 \mathrm{~m}$.

The Stornorrfors power station (four Francis-turbines) has a maximum capacity of c. $1000 \mathrm{~m}^{3} \mathrm{~s}^{-1}$, and legislation requires minimum spills to the bypass of $10 \mathrm{~m}^{3} \mathrm{~s}^{-1}$ from 20 May to 15 June and $15-50 \mathrm{~m}^{3} \mathrm{~s}^{-1}$ from 15 June to 1 October. Large spills can occur during periods of extreme discharge from melting snow during the spring- and mountain floods, and no water is released into the bypass from 1 October to 20 May. The fish ladder flow is maintained at c. $1 \mathrm{~m}^{3} \mathrm{~s}^{-1}$, and spill flows of up to $19 \mathrm{~m}^{3} \mathrm{~s}^{-1}$ act as an auxiliary source of attraction water (to the ladder). Bypass channel flows during the salmon migration period from 20 May to 1 October (measured by the power station company Vattenfall $\mathrm{AB}$ ) during the years of this study varied from relatively low volumes with an average of $23 \mathrm{~m}^{3} \mathrm{~s}^{-1}$ in 2003 (max flow: $85 \mathrm{~m}^{3} \mathrm{~s}^{-1}$ ) to a maximum of $2022 \mathrm{~m}^{3} \mathrm{~s}^{-1}$ in 1995 (average: $182 \mathrm{~m}^{3} \mathrm{~s}^{-1}$ ). Average turbine flows during the study were $569 \mathrm{~m}^{3} \mathrm{~s}^{-1}$, lowest in $1996\left(297 \mathrm{~m}^{3} \mathrm{~s}^{-1}\right)$ and highest in $2001\left(806 \mathrm{~m}^{3} \mathrm{~s}^{-1}\right)$. Bypass flows were experimentally altered from normal levels during the salmon upstream migration periods in 2001-2005. In 2001 artificial freshets of $70-120 \mathrm{~m}^{3} \mathrm{~s}^{-1}$ were released from the dam for about $30 \mathrm{~h}$ three times and in $200280 \mathrm{~m}^{3} \mathrm{~s}^{-1}$ were released for $78 \mathrm{~h}$ on two occasions, while $50 \mathrm{~m}^{3} \mathrm{~s}^{-1}$ were spilled for $75-102 \mathrm{~h}$ 
three times in 2003. In 2004 a major flood resulted in spills of up to $1600 \mathrm{~m}^{3} \mathrm{~s}^{-1}$ in the middle of the salmon migration period (8-21 July), while spills thereafter were altered in July-August from the normal levels by releasing $50 \mathrm{~m}^{3} \mathrm{~s}^{-1}$ for $8 \mathrm{~h}$ at nights and $20 \mathrm{~m}^{3} \mathrm{~s}^{-1}$ for the remainder of the day. In 2005 the spill flow amounts were modified according to a model by Leonardsson et al. (2005), which aimed to optimise the upstream migration of salmon past the confluence area and the first rapid in the bypass channel while minimising the losses of power production due to the increased spills. This resulted in $90 \mathrm{~m}^{3} \mathrm{~s}^{-1}$ released during one 60 -h period and $80 \mathrm{~m}^{3} \mathrm{~s}^{-1}$ was released for $156 \mathrm{~h}$ during the subsequent event.

The ambient river temperature during the study years ranged from 8 to $10^{\circ} \mathrm{C}$ in early June with a peak of $20-23^{\circ} \mathrm{C}$ in July-August. Thereafter it dropped slowly to about $4-6^{\circ} \mathrm{C}$ by October (data from Vattenfall $\mathrm{AB}$ ). In 2001, hourly variation in water temperature was measured in the lower part of the bypass channel and at the turbine outlet (Onset-TidBit temperature loggers). The data showed only minor differences between the two locations, and the mean daily water temperature at the outlet was on average c. $0.2-0.3^{\circ} \mathrm{C}$ lower than in the bypass. Nevertheless daily temperature differences were greater in the bypass channel $\left(2-3^{\circ} \mathrm{C}\right)$ than in the turbine outlet $\left(0.5-1{ }^{\circ} \mathrm{C}\right)$.

\section{Tagging and tracking of salmon}

During the nine-year period between 1995 and 2005, various tags were used to study salmon migrating upstream after their capture in a hoop-net at the mouth of River Umeälven, $63^{\circ} 41^{\prime} 36^{\prime \prime} \mathrm{N} \quad 20^{\circ} 19^{\prime} 45^{\prime \prime} \mathrm{E}$ (Fig. 1). The earliest tagging occurred on 3 June (1996) and the latest on 29 August (1996). In total, 2650 salmon were tagged (Table 1) with either external radio tags, gastric radio tags, passive integrated transponder (PIT) tags or external Carlin-tags. The handling, tagging and genetic sampling of fish followed Rivinoja (2005) who, together with references therein, reported that these tags are unlikely to affect the swimming performance of adult salmon. The annual number of tagged fish varied from a minimum of 30 radio tags in 1995 to a maximum of 573 Carlin tags in 1996. The total lengths $\left(L_{\mathrm{T}}\right)$ of tagged salmon ranged from 39 to $116 \mathrm{~cm}$. Annual mean sizes varied between years $(P<0.05$, d.f. $=8,2648$, ANOVA $)$

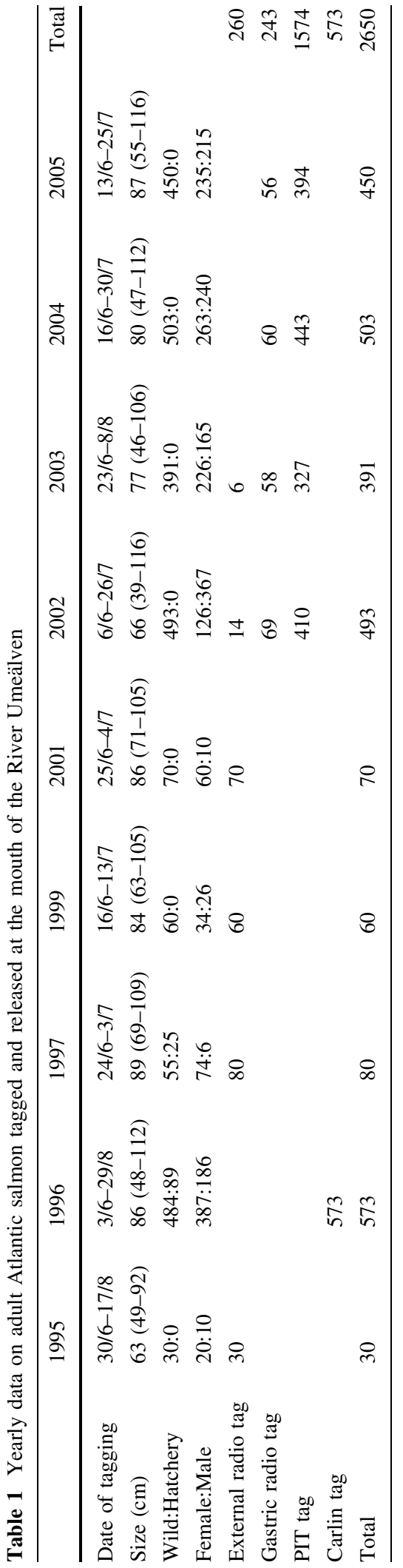


from a minimum of $63 \mathrm{~cm}$ (S.D. \pm 12.5$)$ in 1995 to a maximum of $89 \mathrm{~cm}$ (S.D. \pm 9.9) in 1997. Larger salmon (mostly females) arrived earlier in the lower river and at the fish ladder than smaller salmon, as was reported by McKinnell et al. (1994). Beginning in 1999, radio-tagged salmon were tagged with a PIT tag and a small cut or puncture on the adipose fin (Rivinoja et al., 2006), so that tagged fish could be identified at the ladder even if a salmon had lost its radio tag. Genetic analyses of the radio-tagged fish that passed the first archival receiver indicated that all fish belonged to the River Vindelälven population which has a uniquely high frequency of a particular composite haplotype (Vasemägi et al., 2005).

Radio-tagged fish were frequently located in the regulated part of the river using manual receivers (ATS R2100, Televilt RX8910) from a boat or from the shore. The exact positions of radio tags were needed to determine both the positions of the salmon and to ascertain whether a tag had become detached from its host. Automatic archival receivers (LOTEK SRX_400 with 4 or 9-element Yagi-antennas) were used at the confluence area and further up- and downriver (Fig. 1). From 1995 to 2003 the first archival receiver was located in Umeå c. $6 \mathrm{~km}$ downstream of the confluence area, while in 2004 and 2005, it was moved c. $4 \mathrm{~km}$ upriver of its previous position to study a narrower area (Fig. 1). The fish ladder and adjacent rapids were covered with receivers in 2001, 2002, 2004 and 2005. Since the average loss of external radio tags over the years 1995-2001 was $22 \%$, gastric-implanted tags were used after 2001 to reduce tag losses. The average loss of radio tags was lowered to about $7 \%$.

Echo-sounding in the turbine outlet area

Echo-sounding as described by Lilja (2004) was performed with a hydro-acoustic split-beam echosounder (Simrad EY60, GPT $200 \mathrm{kHz}$ ) at the turbine outlet area (Fig. 1). The positional data and directional movements of adult salmon were recorded from a boat in 2004 and 2005. The equipment was connected to a computer running ER60 software that recorded data together with a GPS (Geographical Positioning System, U2 SIRF Star II, WAASEGNOS). The equipment was calibrated at the top of the fish ladder using salmon of known size. At the turbine outlet area, echo-sounding was carried out on various dates during the migration using various transducer angles and depths, but mainly at a compass heading of $200^{\circ}$ from a position located at $63^{\circ} 50^{\prime} 8.6^{\prime \prime} \mathrm{N} 20^{\circ} 7^{\prime} 32.6^{\prime \prime} \mathrm{E}$. At each recording, the transducer depth and angle was noted, and the data were analysed with the post-processing software Sonar 5 (Balk \& Lindem, 2004).

Modelling effects of power station losses on population dynamics

A model with basic data (Table 2) from ICES (2001), together with values from Rivinoja et al. (2005) and own unpublished data (Department of Aquaculture, SLU), was used to predict how improved upstream migration success of adult spawners past the regulated river section might affect future escapements of the spawning stock to River Vindelälven. The following assumptions were made:

- Eggs hatch and juveniles remain in the river for 2-3 years with survival $p_{X}$, where $X$ is age.

- The probability of smolting at age $2+$ is given by $p_{S}$ while the rest smoltify as $3+$ (dependent on local adaptations and river-specific growth conditions).

- Age 2+ and 3+ smolts migrate seawards and are exposed to reduced survival at the power station $\left(p_{T}\right)$ and due to natural mortality $\left(p_{3}\right)$ during the migration to the Baltic, where the single-survival stages are multiplied to estimate the real product outcome.

- The probability of survival at sea decreases substantially with increasing age due to the Baltic fishery, which was assumed to remain unchanged during the time frame modelled.

- The probability of returning to the river $\left(p_{A X}\right)$ for spawning, given that the individual is alive, increases with age.

- The probability of reaching and ascending the fish ladder is given by $p_{U}$.

- The unsuccessful fraction $\left(1-p_{U}\right)$ returns to the sea without spawning, but may return the following year.

- All kelts die at the power station during their seaward migration.

With the above model formulation, the outcome of improving smolt survival during their seaward 
Table 2 Description of parameters in the Leslie matrix and their numerical values

\begin{tabular}{|c|c|c|}
\hline Parameter & Numerical value & Description \\
\hline \multicolumn{3}{|c|}{ Probability of survival } \\
\hline$p_{0}$ & $0.025-0.125$ & During the first year after hatching \\
\hline$p_{1}$ & $0.40-0.60$ & In the river from ages 1 to 2 \\
\hline$p_{2}$ & $0.40-0.60$ & In the river from ages 2 to 3 \\
\hline$p_{3}$ & $0.06-0.80$ & $\begin{array}{l}\text { During the smoltification year, includes seaward migration and the first season in the sea. Assumed } \\
\text { same for the 2- and 3-year-old smolts }\end{array}$ \\
\hline$p_{4}$ & $0.60-0.80$ & In the sea between ages 4 and 5 \\
\hline$p_{5}$ & $0.05-0.15$ & In the sea between ages 5 and 6 \\
\hline$p_{6}$ & $0.025-0.075$ & In the sea between ages 6 and 7 \\
\hline$p_{7}$ & $0.025-0.075$ & In the sea each year after age 7 \\
\hline \multicolumn{3}{|c|}{ Proportion of } \\
\hline$p_{A(4)}$ & $0.005-0.015$ & 4-year females returning to river \\
\hline$p_{A(5)}$ & $0.10-0.30$ & 5-year females returning to river \\
\hline$p_{A(6)}$ & $0.80-1.00$ & $\begin{array}{l}\text { 6-year females returning to river. Older females are assumed to always aim for a return migration } \\
\text { to the river }\end{array}$ \\
\hline$p_{R}$ & $\begin{array}{l}\mathbf{0}(0.01-0.05 \text { vs. } \\
\quad 0.05-0.15)\end{array}$ & $\begin{array}{l}\text { Spawners returning to the sea could become possible with a downstream bypass. This parameter } \\
\text { also adjusts for reduced maturation size at following spawning occasion }\end{array}$ \\
\hline$p_{S}$ & $0.40-0.60$ & Smoltified at age $2^{\mathrm{a}}$ \\
\hline$p_{T}$ & $\mathbf{0 . 7 5}(1.0,1.09)$ & Smolts surviving passage of turbines or a downstream bypass ${ }^{c}$ \\
\hline$p_{U}$ & $\mathbf{0 . 3}(0.5,0.75)$ & Returning salmon that passes the fish ladder ${ }^{\mathrm{d}}$ \\
\hline \multicolumn{3}{|c|}{ No. of eggs per female of age and weight ${ }^{\mathrm{b}}$} \\
\hline$F_{4}$ & $1260 \pm 10 \%$ & $4, \mathrm{~W}=2.1 \mathrm{~kg}$ \\
\hline$F_{5}$ & $2640 \pm 10 \%$ & $5, \mathrm{~W}=4.4 \mathrm{~kg}$ \\
\hline$F_{6}$ & $5220 \pm 10 \%$ & $6, \mathrm{~W}=8.7 \mathrm{~kg}$ \\
\hline$F_{7}$ & $9600 \pm 10 \%$ & $7, \mathrm{~W}=16 \mathrm{~kg}$ \\
\hline
\end{tabular}

When a range of parameter values is presented, the parameter values were assigned to the numerical values following a uniform random distribution. The numerical values for parameter $p_{3}$ were solved to have a stable initial population size, given all the other parameter values. The bold values denote the observed survival or proportion with existing migration possibilities. (Notes from: ${ }^{a}$ ICES, 2001; ${ }^{b}$ Lundqvist et al., 1994; ${ }^{c}$ Rivinoja, 2005, ${ }^{d}$ this report.) The hypothetical values in note 3 and 4 adjusts for the survival/ return rate improvement

migration as well as improving conditions for the upstream migration of adults could be predicted. The mathematical formulation of the model, where $N_{t}$ is the size (age)-structured population vector containing the number of females in each size-class at time $t$ and
$\mathrm{L}$ is the Leslie matrix containing the survival and fecundity data is:

$$
N_{t+1}=\mathrm{L} \cdot N_{t}
$$

The matrix formulation becomes:

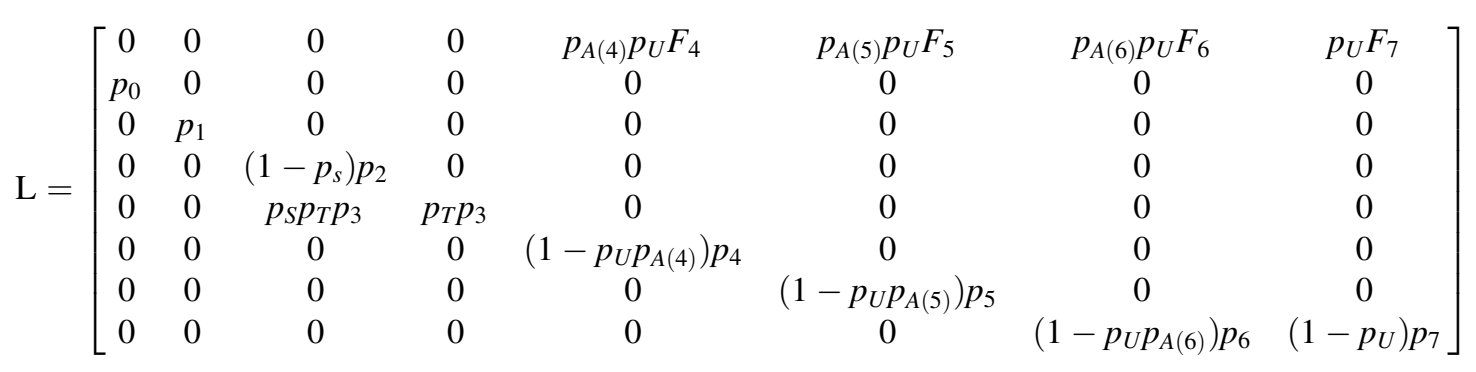


The robustness of the results was checked using a range of parameter values for all parameters except $p_{3}$ and $p_{U}$. The other parameter values were varied 10,000 times, within the ranges given in Table 2, by assuming that all parameter values within the ranges were equiprobable. For each run, the real-valued eigenvectors were scaled to become the initial population vectors yielding a non-growing population consisting of 1000 successfully reproducing females, approximately the number of females that have passed the fish ladder per year in recent years. By increasing the return probability $\left(p_{U}\right)$ and predicted number of fish passing the ladder, the effects on the salmon population size of a hypothetical improvement in upstream migration success were evaluated. The model assumes density-independent growth for the population, justified by recognition of that the present population is far below its potential carrying capacity (ICES, 2001; 2005). Nevertheless, predictions beyond 15-20 years should be considered with caution since density-dependent effects were not included in the model. Mathematica ver. 5.2 (Wolfram Research, Inc. 2005) was used for the calculations.

\section{Results}

Salmon entry from the coast to the river

An average of $83 \%$ (range: $73-93 \%$ between years, Table 3) of all 478 radio-tagged wild fish migrated relatively quickly to the first receiver located 17-21 km upriver (Fig. 1). Individual migration durations in this section ranged from 0.5 to 80 days, and upstream migrations occurred both in day time and at the night (which is not dark at this latitude in summer). All fish that passed the first receiver reached the confluence area where a majority stayed for several days. Although 19 tagged fish were recaptured by fishermen at the coast of the Bothnian Bay, the fate of most of the $17 \%$ of radio-tagged individuals that were never registered in the river remains unknown. Four radio tags were lost near the tagging site.

Migration in the confluence area

In the confluence area between the power station outlet and the bypass channel, salmon generally

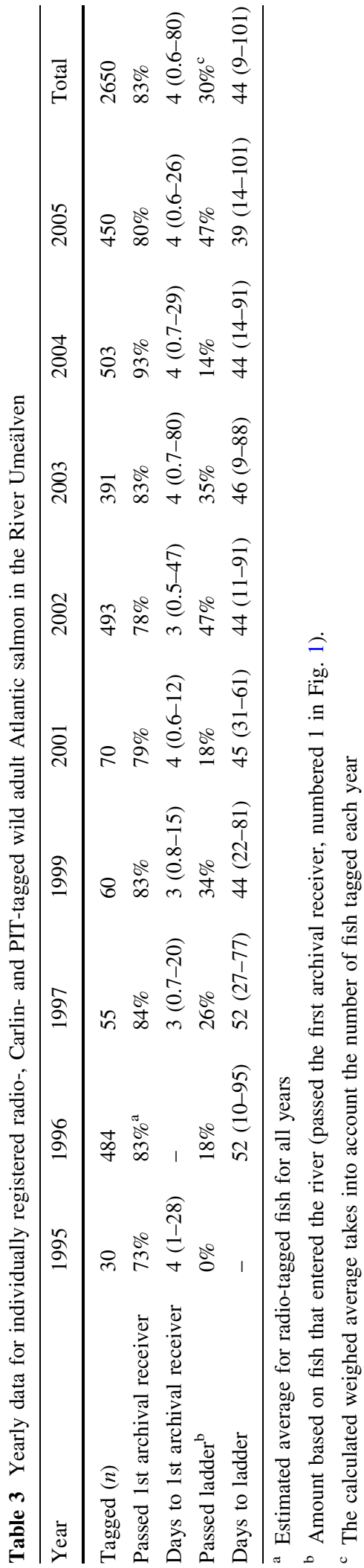


followed the large flows from the turbine outlet. During periods with high turbine discharge and low bypass flow, fish were attracted from the bypass channel, delaying their upstream migration. Most salmon that reached this area spent a relatively long time (min-max: 1-82 days, mean: 12 days, median: 9 days) in the high flows below the turbine outlet before ascending into the bypass channel. Salmon showed mainly three migratory responses in relation to the flow regimes:

(1) located in the turbine outlet, moving up- and downstream in the main stem depending on turbine flows in search for an upstream route. Some of these fish entered the bypass channel, yet stayed only for a limited time which caused unsuccessful advancement for further upstream migration,

(2) entered the bypass channel and held positions for a relatively long time below the first rapid at Baggböle without passing upriver. Increasing spill flows into the bypass channel generally attracted the salmon upstream, yet fish in the bypass responded to both increasing and decreasing spill flows by exhibiting downstream movements,

(3) entered the bypass channel and moved continuously upstream. Successful upstream passages of these rapids generally occurred at spill flows $<200 \mathrm{~m}^{3} \mathrm{~s}^{-1}$.

These migratory responses were consistent for all years when telemetry was used to understand the positions of radio-tagged salmon. A four-year evaluation (adequate data obtained in 1997, 1999, 2001 and 2002) of up- and downstream movements of radiotagged salmon in the main stem of the river, demonstrated that many salmon that were recorded in the tunnel outlet area had directed downstream movements and were registered on the receiver located in Umeå c. $6 \mathrm{~km}$ downstream the turbine outlet. On average, about $40 \%$ of all radio-tagged salmon that reached the confluence area in the years of this study (106 of a total of 268), 26\%, 27\%, 53\% and $48 \%$ in 1997, 1999, 2001 and 2002, respectively, returned downstream at least three times and were registered on the receiver in large numbers over the whole 24-h period. For example, in 2001, the 55 salmon that began their upstream migration passed over the downstream receiver 174 times with a maximum of 11 detections recorded for each of two. In general, most downstream movements were observed c. $7 \mathrm{~h}$ after the turbine discharge had decreased, while some of the registrations took place when the discharge increased. In 1997 wild $(n=11)$ and hatchery salmon $(n=13)$ showed similar up- and downstream movements at the receiver. Combined data indicated that the number of registrations at the downstream receiver decreased in late summer (beginning in August), yet no relationship between the number of registrations in this area versus salmon sex or size, nor the date of tagging was found (Fig. 3). Nevertheless, a comparable behavioural pattern, where fish responds to rapid changes in flow regimes, was observed in all the years and we coin the expression "yo-yo migration" for this type of salmon behaviour.

Echo-sounding in the turbine outlet area

At the confluence area, both tagged and untagged salmon were observed to enter the turbine outlet repeatedly, indicating that the salmon were searching for an upstream route. Echo-sounding in this area revealed that the salmon were predominantly found near the surface (1-4 m depths). An event on 5th August 2004 demonstrated these yo-yo migrations, with about $70 \%$ of all movements directed downstream (dotted grey line in Fig. 4, left). Salmon at this area were also observed to dive to the bottom at depths of up to $40 \mathrm{~m}$ and also swim back and forth over the whole channel width (Fig. 4, right).

Salmon migrations from the confluence area to entry of the bypass channel

Data collected from 1997 to 2003 showed that salmon generally spend a long time in the confluence area before ascending the bypass channel; however, most fish in the confluence area responded to increased spill flows and moved quickly into the bypass. Fish reached the first rapid at Baggböle, immediately upstream of the entrance to the bypass, after an average over all years of c. 13 days (median $=10$ days) after tagging. On average, they passed this section of the river after c. 25 days (median $=14$ days). Detailed modelling of the relationship between bypass flow and the proportion of upstream migrating salmon passing the rapid at Baggböle is presented by Leonardsson et al. (2005). Data from 


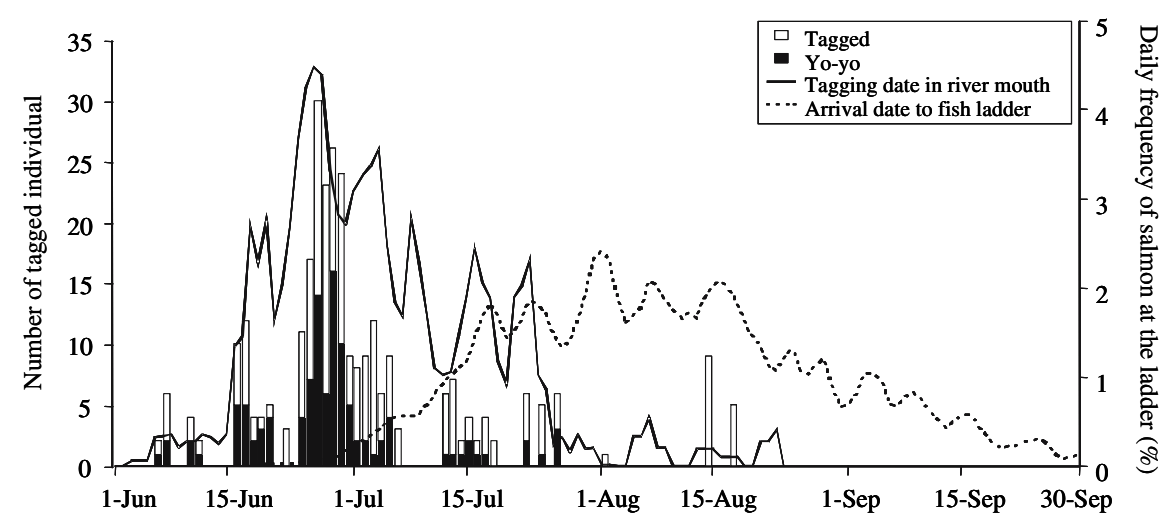

Fig. 3 Number of wild radio-tagged salmon showing "yo-yo movements" between the confluence area and the archival receiver in Umeå, $6 \mathrm{~km}$ downstream, in relation to tagging day. A total of 106 out of 268 radio-tagged salmon passed the archival receiver at least three times, resulting in 1992

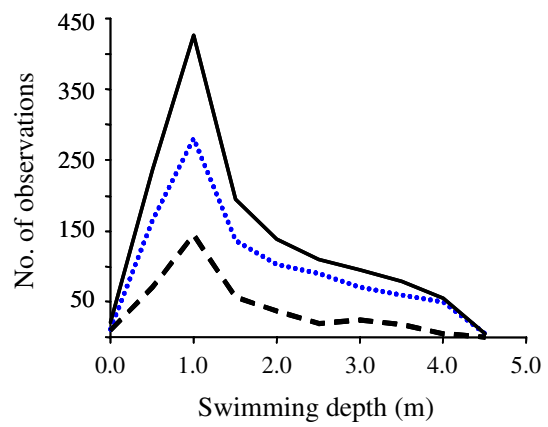

Fig. 4 Salmon in the turbine outlet channel were mainly $<4 \mathrm{~m}$ deep (left figure) and showed up- and downstream movements over the whole channel width (right figure). The solid black

2001 and 2003 illustrate the typical migration responses of radio-tagged salmon at the confluence area in relation to flows (Figs. 5, 6). In 2001, flows in the bypass channel were increased in the weekend to $50 \mathrm{~m}^{3} \mathrm{~s}^{-1}$, a normal discharge pattern at this dam. At the first period (30 June-2 July) only 2 of the 21 salmon located in the confluence area successfully ascended to the bypass channel, but when the bypass flow was increased to $200 \mathrm{~m}^{3} \mathrm{~s}^{-1}$ (7-8 July) the fraction increased to 13 of 28 (Fig. 5). For 10 days (20-30 July) when excess flows were spilled (on average $\left.160 \mathrm{~m}^{3} \mathrm{~s}^{-1}\right)$, numerous upstream $(n=36)$ and downstream $(n=16)$ movements of radiotagged salmon were observed in the lower part of the bypass channel and also passages $(n=11)$ of the waterfall were observed. Similarly, data from 2003 (Fig. 6) show that upstream migration to the bypass increased with the amount of spill, and in addition, registrations in the four years $(97,99,01$ and 02$)$. The total number of wild salmon tagged per day is illustrated by the black line, while the dashed line shows the relative frequency of salmon arrival date to the ladder

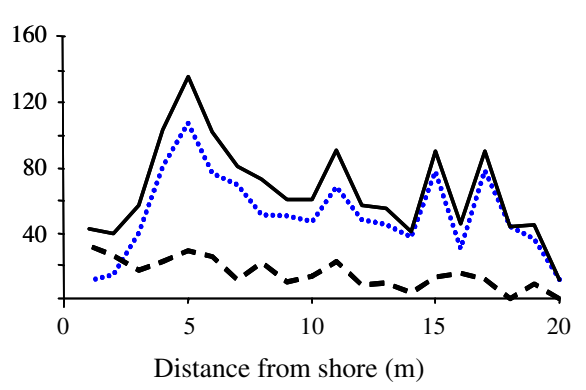

line show total observed movements, the dotted grey line downstream movements and the dashed black line upstream movements (recorded on 5th August 2004)

that turbine flows below $200 \mathrm{~m}^{3} \mathrm{~s}^{-1}$ facilitated salmon bypass ascent. Most salmon entered the bypass during periods of reduced ambient light at the night time hours (Fig. 6).

Overall responses to flows (Fig. 7) confirmed that increased spill flows and lower turbine flows generally attracted salmon to the bypass. Yet, at the same time, the waterfall Baggböle near the bypass entrance could also hinder the upstream migration as salmon seemed to hold and even move downstream from the bypass if the spill flows exceeded $150-200 \mathrm{~m}^{3} \mathrm{~s}^{-1}$ (see also Leonardsson et al., 2005). By correlating bypass flows with fish responses in the area just below this waterfall, different discharges were evaluated to see how flows could initiate or hinder fish migrations. Over the salmon migration period in 1997 the mean spill flow when salmon successfully entered and passed the bypass channel and the rapid was 
Fig. 5 Registrations $(n=121)$ of directional salmon movements (black bars) and bypass flow (grey area) from 30th June to 17 th August 2001. The short bars indicate salmon entry from the confluence area to the bypass, the intermediate bars downstream migration from the bypass and the long bars salmon upstream passage of the first rapid in the bypass. The majority of registrations took place during the high spill flow period in late July

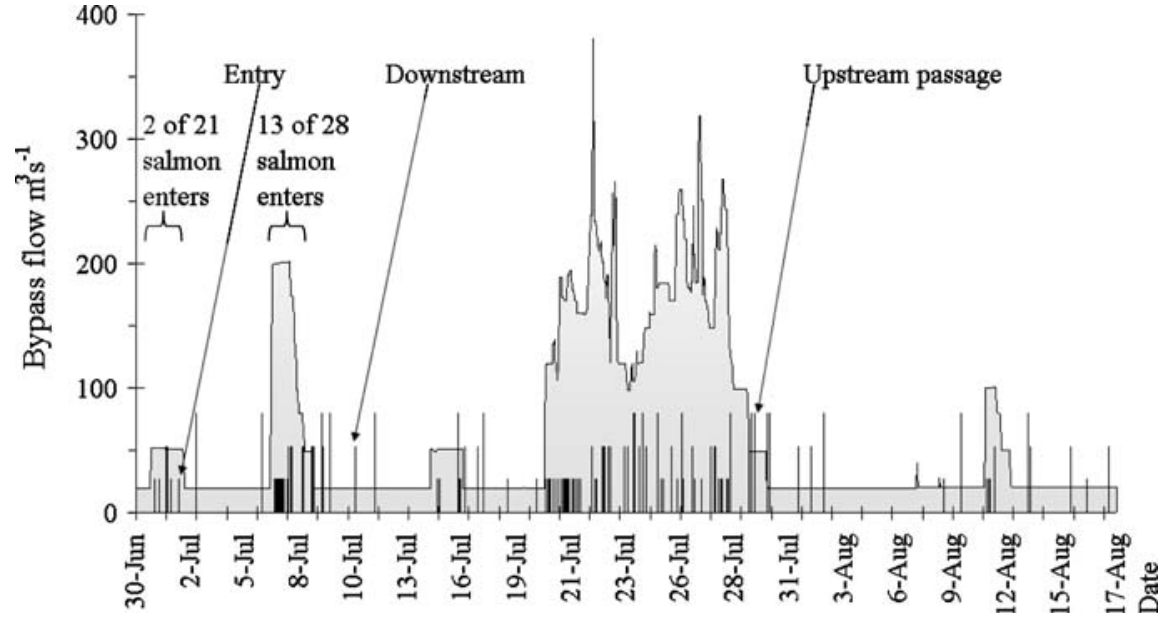

$150 \mathrm{~m}^{3} \mathrm{~s}^{-1}$ (Rivinoja et al. 2001), while flows higher than these might cause unsuccessful passage regardless of the turbine discharge. From an event in 2002 (25 June-12 July), the migration at flows of 50 and $80 \mathrm{~m}^{3} \mathrm{~s}^{-1}$ showed how salmon responded to the increased flows within a few hours by moving upstream into the bypass and then stopped their upstream migration at the rapid (Fig. 8). A decreased discharge from 50 or $80 \mathrm{~m}^{3} \mathrm{~s}^{-1}$ to $20 \mathrm{~m}^{3} \mathrm{~s}^{-1}$ caused $50 \%$ of the salmon to pass the rapid and move upriver (7 out of 14 fish), while the remaining fish returned downstream to the confluence area. Similar fish migration patterns were manifested over the years for other periods with increased spills.

Fig. 6 Radio-tagged salmon at the confluence area $(n=34)$ entered the bypass channel more frequently at turbine flows below $200 \mathrm{~m}^{3} \mathrm{~s}^{-1}$, at higher dam spills and during the night hours. (Data from year 2003)
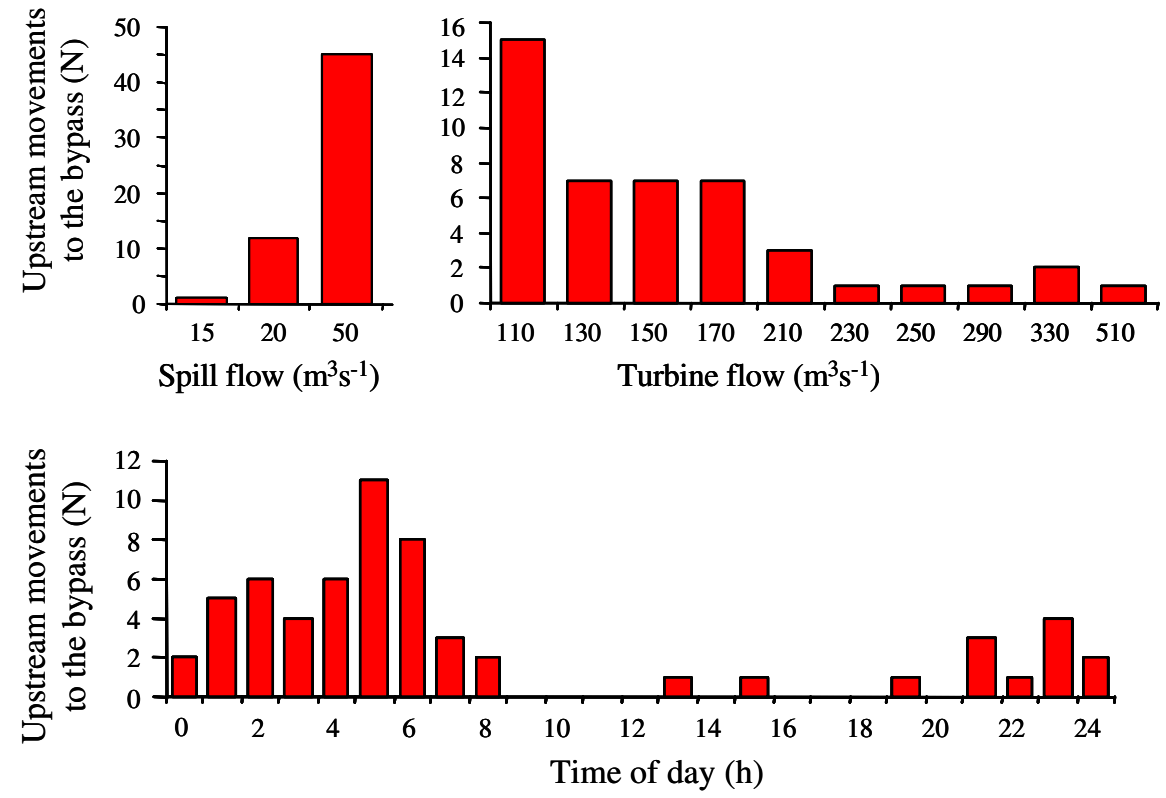

Time of day (h)
Upstream migration from the bypass channel to the fish ladder

After passing the rapid at Baggböle, the salmon migrated relatively quickly, of the order of 1-2 days, c. 6-7 km, upstream to the rapids immediately below the entrance to the fish ladder. At these rapids (N. Kungsmofallet, Ö. Kungsmofallet and Laxhoppet) the salmon had additional problems to pass, showing a slight delay and unsuccessful upstream passages; however, the migration behaviour of fish at these rapids was not so closely monitored. Nevertheless, the receiver at the fish ladder area indicated that both upand downstream movements occurred at the uppermost 


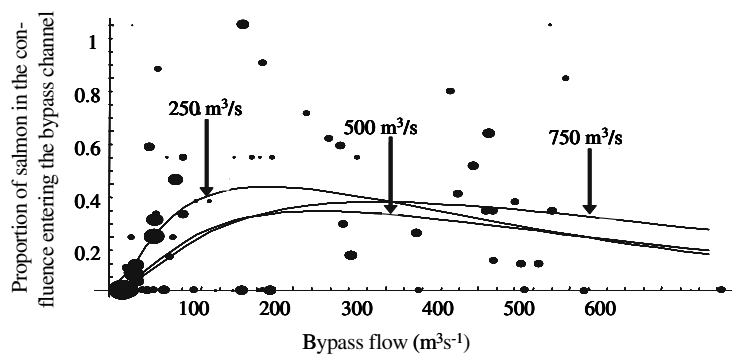

Fig. 7 Salmon in the confluence area mainly entered and passed further upstream in the bypass channel at spill flows below 150-200 $\mathrm{m}^{3} \mathrm{~s}^{-1}$. Non-linear response curves for turbine flows of 250-750 $\mathrm{m}^{3} \mathrm{~s}^{-1}$ shows the effects on the ascent of fish to the bypass. The size of each plot point is scaled from 1 to 597 to indicate the number of salmon registrations (from Leonardsson et al., 2005)

rapid below the fish ladder and that some salmon repeatedly entered the ladder without ascending. The receiver at the fish ladder showed that fish $(n=58$ in 2001, 2002, 2004 and 2005) entered the ladder at spill flows that varied between 15 and $105 \mathrm{~m}^{3} \mathrm{~s}^{-1}$, with an average of $32 \mathrm{~m}^{3} \mathrm{~s}^{-1}$. Upstream movement of radiotagged salmon through the ladder was highest when attraction water of $19 \mathrm{~m}^{3} \mathrm{~s}^{-1}$ was directed towards the ladder entrance; the proportion of ascending fish decreased at spills in excess of this. There was a tendency for salmon to enter the ladder more frequently in afternoons and early evenings than at night hours. Ladder flows were normally held constant at c. $1 \mathrm{~m}^{3} \mathrm{~s}^{-1}$, yet the swim through time among radiotagged individuals in the ladder showed large disparity, varying from 3 to $133 \mathrm{~h}$ with an average of $35 \mathrm{~h}$. Fish size $(P=0.62, t$-ratio $=0.502)$ or day at tagging $(P=0.94, t$-ratio $=0.074)$ was not related to the travel time through the fish ladder $(n=58$, d.f. $=2$, Cox regression). However, the average duration in the ladder for male salmon (mean $=25.8$ h, S.D. \pm 16.8 ) was significantly faster $\left(P<0.05, \chi^{2}=5.438\right.$, Cox regression) than for females (mean $=41.0 \mathrm{~h}$, S.D. \pm 28.5$)$. During these periods, the river temperature ranged from 9.2 to $20.8^{\circ} \mathrm{C}$ (average $17.3^{\circ} \mathrm{C}$ ), yet no influence of river temperature on salmon travel time through the ladder was detected.

Salmon reaching the top of the fish ladder had spent an average of 44 days from the river mouth to the top of the ladder (Table 3). Individual migration time to the ladder differed greatly within years, but not between years, according to the data obtained from all tagged fish $(n=565)$ in 1997-2005 $\left(P=0.195\right.$, d.f. $=6$, durations $\log _{10}$-transformed, Tukey's Post Hoc). Similarly, travel time to the ladder was independent of the sex of the fish $\left(P=0.377\right.$, d.f. $=1, \chi^{2}=0.781$, Cox regression $)$ or size $(P=0.628, t$-ratio $=-0.485)$, yet travel time was related to the day of tagging; fish tagged early had longer travel time before passing the fish ladder $(P<0.01, t$-ratio $=4.337)$.

Overall migration success, cumulative losses and population modelling

The overall results of taggings from 1995 to 2005 $(n=2650)$ revealed that most of the salmon that

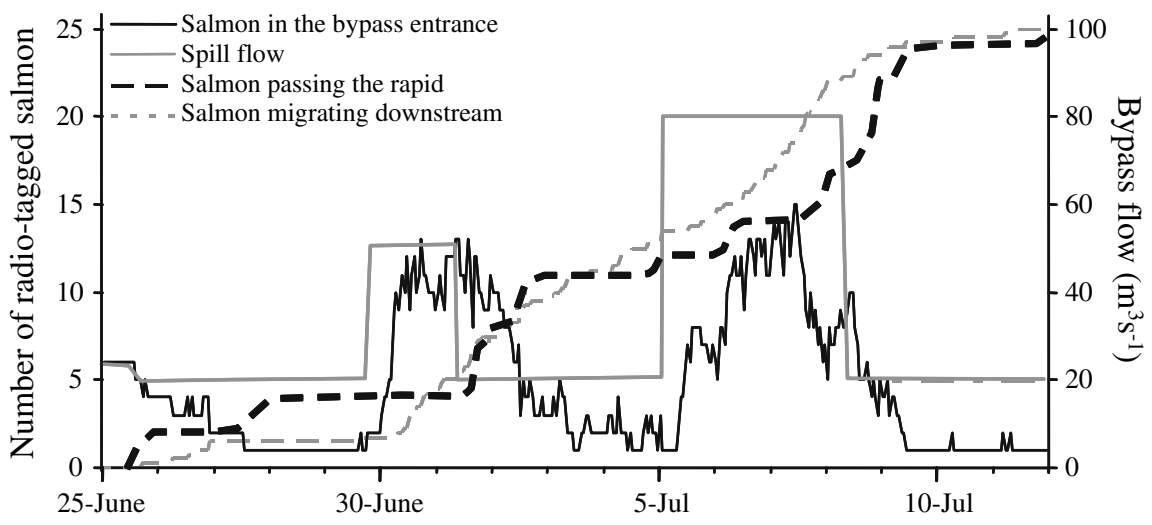

Fig. 8 Radio-tagged salmon from the confluence area rapidly entered the bypass (black line, left axis) when spill flow was increased from $20 \mathrm{~m}^{3} \mathrm{~s}^{-1}$ to 50 or $80 \mathrm{~m}^{3} \mathrm{~s}^{-1}$ for two and four days, respectively (grey line, right axis). About half of the fish passed upstream (cumulative number of salmon passing the rapid, black dashed line) both at increased and decreased flows, while the other half migrated down to the confluence area (cumulative number of salmon moving downstream to confluence area, grey dashed line) 
initiated their migration to the spawning grounds of the Vindelälven were unable to migrate from the river mouth to the top of the fish ladder. On average only $30 \%$ (a weighted average that accounts for the numbers of tagged fish per year) of all tagged fish were able to pass the regulated river stretch (Fig. 9). The proportion of wild salmon passing the fish ladder varied from $14 \%$ to $47 \%$ from 1996 to 2005 , and none of the radio-tagged fish succeeded in 1995. The correlation between the percentage of tagged fish that passed the ladder and the mean annual spill was statistically significant $(P<0.05, \quad r=-0.73$, $r^{2}=0.53$, d.f. $=1,7$, Linear regression), but this result was heavily influenced by the results of 1995 when the spring flood was high (up to $2000 \mathrm{~m}^{3} \mathrm{~s}^{-1}$ ) in most of June. If this outlier was omitted from the analysis, the correlation between average spill and migration success was not statistically significant $\left(P=0.247, r=-0.46, r^{2}=0.21\right.$, d.f. $=1,6$, Linear regression), although we note that the second highest mean annual spill (2004) concurred with the second lowest migration success at the ladder. The highest overall success rates were observed in 2002 and 2005 (Table 3), years with relatively low and stable spills, perhaps increased by the artificial freshets provided by the regulations to ensure minimum spill volumes. In these years flows of 80 and $90 \mathrm{~m}^{3} \mathrm{~s}^{-1}$ were spilled, while maximum spills rarely exceeded these amounts. On the whole, over the years, radio-tagged salmon showed prolonged migration time at the confluence area, that explained the long average travel time of 44 days from the river mouth to the fish ladder. Salmon were partially hindered at rapids in the bypass channel that resulted in delays and reduced upstream passage success according to the flow regime. Of all observed losses of upstream migrants over the years (Fig. 9), a loss of c. $50 \%$ was observed at the confluence area and the first rapid (Baggböle) in the bypass channel. Additional losses of c. $20 \%$ occurred at the rapids in the upper part of the bypass channel (N. Kungsmofallet, Ö. Kungsmofallet and Laxhoppet), and the remaining c. $30 \%$ was related to problems for the salmon to find and pass the fish ladder. After the radio-tagged fish were released upstream of the fish ladder they reached their main spawning areas, $210-250 \mathrm{~km}$ upstream in Vindelälven in about 10-15 days after passing several major rapids and climbed an altitude of about $200 \mathrm{~m}$ (Lundqvist et al., 2006).

In 1997 data obtained from radio-tagged hatchery salmon indicated that a majority of these fish were unable to find and pass the bypass channel, and none of the hatchery salmon passed the ladder, perhaps because their release locations were immediately below the dam. Complementary data from 1996 demonstrated that a lower proportion of hatchery salmon (8\%) than wild salmon (18\%) passed that ladder. Additional data, analysed for the years 2002 and 2003, demonstrated that radio-tagged wild salmon had the same migration success from the tagging site to the fish ladder as the control group of PIT-tagged salmon (Rivinoja et al. 2006).

The population dynamics model suggests that if the passage problems in the regulated river sections

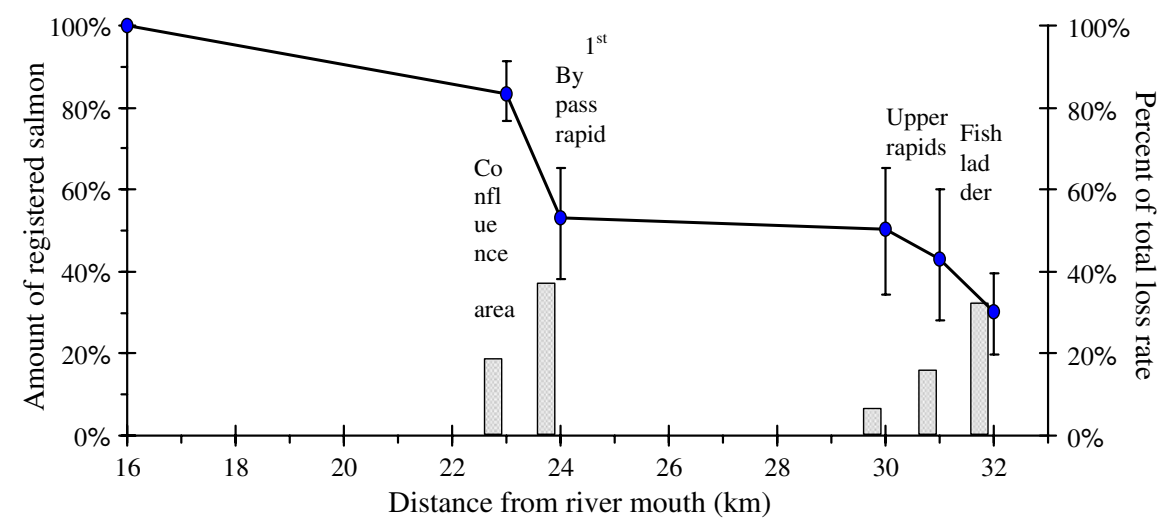

Fig. 9 The cumulative passage success of wild salmon past various areas upstream of the tagging-site (left axis) where the bars indicate the $75 \%$ percentiles. A total of 478 radio-tagged salmon that entered River Umeälven from 1995 to 2005 is included in the data. The proportion of the total losses of salmon (unsuccessful passages) at problematic areas is denoted by the grey boxes (right axis) 
were alleviated, an increase of $500 \%$ in the escapement returns should be expected after 10 years if the number of fish reaching the spawning areas could be improved from the current $30 \%$ to $75 \%$ (Fig. 10), assuming that spawning and rearing habitats are not limiting the natural production of juveniles in the Vindelälven. The corresponding increase for a migration success of $50 \%$ gives a yearly population abundance increase of $9 \%$; the total increase after 10 years would be $160 \%$ over current levels.

\section{Discussion}

The probability of wild salmon successfully migrating through the regulated part of the River Umeälven from the estuary to the fish ladder is low, with average losses of c. $70 \%$ of potential salmon spawners. Gowans et al. (2003) reported large cumulative negative effects on fish migration in rivers with numerous obstacles and that this affected the escapement returns to the spawning areas. The large variation in migration success among years (minmax: $0-47 \%$ ) is not easily explained. It may have been the result of extra spill water with stable discharges in the bypass, as in 2002 and 2005. Years of generally unsuccessful upstream migration had large differences in bypass flows and high spills, which can explain the low success rates in 1995 and 2004.

In River Umeälven, migration problems occurred in different parts of the flow-controlled areas, but the greatest losses $(50 \%)$ of salmon took place where the turbine discharge water joins the bypass flow. Here the complex flow patterns and large turbine flows directed salmon away from the upstream routes. Areas with these characteristics can be major

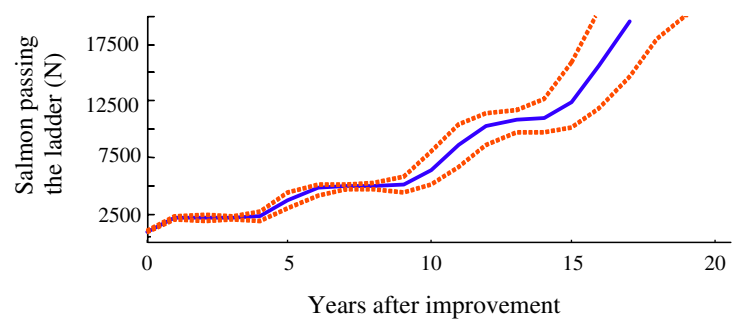

Fig. 10 Predicted number of adult salmon females passing the fish ladder during a 20-year period after improved upstream migration from $30 \%$ to $75 \%$ at the regulated part of the River Umeälven. An estimated yearly population increase of $18 \%$ is expected, and after 10 years the population has increased about $500 \%$. Stroked line shows the $95 \%$ CI hindrances for upstream migrating fish (Arnekleiv \& Kraabøl, 1996; Karppinen et al., 2002; Thorstad et al., 2003). Ferguson et al. (2002) explained the discharge-seeking behaviour as an evolved mechanism that maximises spawning success since fish attracted to the highest discharge normally follow the main branches of rivers on their way to the spawning grounds. As shown here and also by Arnekleiv \& Kraabøl (1996) in studies on brown trout, successful upstream migration of fish to bypasses was positively related to spillway flow, and fish could stop their migration if they were guided towards turbines. In addition, Ferguson et al. (2002) pointed out that during situations of low spill, fish might lose the attraction cues from bypasses, which may prevent or impede adult fish from migrating upstream.

Another important finding in this study was that salmon that reached the turbine outlet and confluence area moved several kilometres downstream, mainly when turbine discharge was lowered. Arnekleiv \& Kraabøl (1996) also observed this restless behaviour of fish and noted that up- and downstream movements of several kilometres occurred. These "yo-yo migrations" delayed migration and caused increased swimming behaviour with associated energetic costs for the fish. These costs cannot be recovered because maturing anadromous salmon do not feed while in freshwater. Lower fat reserves will potentially lower the fitness of individuals during competition for mates and may lead to lower overwinter survival, which would amplify the negative effects on the population.

Salmon positioned at various sites in the confluence area responded strongly to increased spill in the bypass channel in combination with lower flows from the turbine outlet. At these events fish generally migrated quickly into the bypass channel, but occasionally without passing the first rapid c. $1 \mathrm{~km}$ upstream of the confluence area. During periods with high spill flows (e.g. spring flood) a subsequent reduction in spill volume could facilitate passage of the rapid. Likewise, a reduction in spill flow may also cause downstream migration from the rapid. It is commonly known that salmon tend to aggregate in areas with partial barriers and the rapids in the bypass could act as such barriers. In addition, these delays prolong the upstream migration time which can also cause failure to pass further upstream (Power \& McCleave, 1980; Webb, 1990; Rivinoja et al., 2001). Migrating salmon in natural flows have also been 
shown to exhibit upstream migration at both decreasing and increasing flows (Trépanier et al., 1996). It might be that fish have locally adapted behaviours in relation to river-specific conditions and their physiological status, e.g. salmon might stop and wait at rapids for suitable conditions for passage, and as was shown in this study, high flows can hinder and delay the upstream migration. This behaviour indicates the complex nature of salmon upstream migration, since the location of a fish at any time probably influences its response to increasing or decreasing flows.

Regardless of the problems in the confluence area and the first rapid in the bypass channel, an equivalent loss was observed when one sums the losses at rapids further upriver (20\%) and in the fish ladder area (30\%). Ferguson et al. (2002) argued that the existing fish ladder is not designed properly to attract fish and secure their passage. They stressed that a successful upstream passage facility should pass more than $95 \%$ of the migrating adult fish. In regulated rivers where fish ladders are adjacent to the spillways, water is generally diverted into the lowest parts of the ladders to get better fish attraction at the entrances. Nevertheless, these areas might cause problems for migrating fish since they are influenced by the discharge from the dam combined with the attraction flow leading to fish ladder entrances (Quinn et al., 1997). In the present study, both the proportion of radio-tagged salmon that entered and the proportion that passed the fish ladder decreased when surplus water was spilled outside the ladder. This happened only when the total amount spilled was higher than the normal volume of attraction water supplied to the ladder. Consequently high dam spills could cause difficulties for the fish to locate the fishway entrance and delay the migrants, as has also been shown previously (Bjornn \& Peery, 1992; Quinn et al., 1997). Other studies have described the searching behaviour of fish near fishway entrances (Williams, 1998; Gowans et al., 1999; Karppinen et al., 2002). Laine (1995) mentioned that fish may need to become familiar with the lower parts of the ladder before continuing upstream. Laine (1995) found an average delay of 14 days from the first approach of Atlantic salmon to a ladder until they finally entered, whilst Webb (1990) found delays of 0.6-43 days. Even if it is not possible to determine whether the large variation in passage time among individuals at the ladder in the River Umeälven is normal or not, the relatively long time for salmon to travel through the ladder (up to
$133 \mathrm{~h}$ ), independent of fish size, points out that this ladder is not optimally designed. On the other hand, data presented by Bjornn \& Peery (1992) indicated that duration of passage through fish ladders can vary widely among Pacific adult salmonids (Oncorhynchus sp.). Although river temperature was not found to have an effect on the passage through the ladder in River Umeälven, Gowans et al. (1999) stressed that the ratio of salmon ascending a fish ladder can be positively correlated with temperature.

Our observation that it took on average 44 days for the salmon to migrate the relatively short distance of $32 \mathrm{~km}$ from the mouth of the river to the fish ladder is consistent over decades (McKinnell et al. 1994). They compared the timing of the migration based on numbers of salmon caught daily in the fishery in the lower part of River Umeälven in the early 1980s with the daily counts of salmon at the fish ladder and reported a travel time for multi sea-winter fish from the coast to the fish ladder of c. 40 days. Byström (1867) mentioned a migration time of about 4-6 weeks for salmon from the river mouth to the rapids where the current dam and fish ladder are situated. In that era, before the hydropower developments, other large manmade obstacles (e.g. fish traps) might also have affected or delayed the upstream migration. The initial slow migration process of salmon in River Umeälven might also be an evolved characteristic for the salmon population. The relative steepness of the river from coast to the ladder area (c. $75 \mathrm{~m}$ ), combined with the seasonal high forest- and mountain floods, might have caused an adaptive response for the salmon to wait for decreasing flows in the lower part of the river.

Bjornn \& Peery (1992) found that temperature and turbidity can delay fish migrations. We do not expect that the small daily temperature differences of $\mathrm{c}$. $0.2^{\circ} \mathrm{C}$ between the colder water from the turbine outlet versus the bypass spill would cause the salmon to be directed in any particular way at the confluence area. McKinnell et al. (1994) found no effect of ambient river temperatures on upstream migration of multi-sea winter salmon in River Umeälven. Trépanier et al. (1996) showed only limited effects of temperature on salmon upstream migration. Still, Jensen et al. (1986) observed that Atlantic salmon passages upstream of rapids in a Norwegian river were correlated to increasing water temperature.

The low proportion of salmon migrating from the coast to the ladder might have been influenced by 
their physiological condition. In the last 24 years, outbreaks of the disease M74 have been observed among Baltic salmon stocks (Bengtsson et al., 1999). From 1994 to the beginning of 2000 it occurred in 16-78\% of fish sampled, but thereafter, the incidence of M74 has decreased during the last five years from $45 \%$ in 2000 to $4 \%$ in 2004 (data from Vattenfall $\mathrm{AB})$. No study has revealed a relationship between M74 and migration performance of Atlantic salmon. It is not known if this disease weakens the upstream migration of adults, and even if it did, M74 is not expected to be the one single factor that causes the observed upstream migration patterns of salmon in the regulated part of the river.

\section{Conclusions and management implications for sustaining a salmon stock}

In this study, the major passage problems for migrating wild salmon spawners at the regulated section in River Umeälven occurred at the confluence area. These disturbances caused most Vindelälven salmon to abandon their upstream spawning migration. These migration problems were caused by large variability in flow regimes in the confluence area. The upstream migration was enhanced by increased discharge in the bypass, but too much could hinder the upstream passages. If too low, the salmon entered the turbine outlet. Leonardsson et al. (2005) verified that certain combinations of spillway and turbine flows were found to be beneficial to guide and pass salmon in the correct upstream route, depending on season. Previous observations that enhanced directional cues could affect the fish migration positively (Mills, 1989) and findings that upstream migration rate could be increased by spills (Arnekleiv \& Kraabøl, 1996) or bypass constructions close to turbine outlets (Calles \& Greenberg, 2005) indicate that the upstream migration of salmonids can be managed. Consequently, the migration problems found for adult salmon in the regulated part of River Umeälven could be lowered by: (1) construction of a fishway in the turbine outlet, so salmon could easily find an upstream route, (2) regulation of spill flows to secure successful attraction and passage efficiency of the bypass, and (3) reconstruction of the current fish ladder at the dam to improve passage speed and success. These implementations could be highly favourable for the salmon stock in River Vindelälven since the population models suggested a five-fold increase in spawner abundance within 10 years if the losses at the regulated area could be lowered. Restoration programmes (Nilsson et al., 2005) now undertaken in the River Vindelälven system will increase the amount of spawning habitat, which can enhance future population growth if more spawners were added to the system. Furthermore, efforts taken by the power station owners in River Umeälven to establish a new fish ladder with a downstream guidance device for smolts and kelts suggest a promising scenario for how anadromous fish can be preserved and even enhanced in a regulated river. A variety of designs and techniques to improve migration conditions have been implemented in the USA and Canada for Pacific salmonids (Clay, 1995; Williams, 1998) and more recently in Europe for Atlantic salmon (Larinier, 2002a, b; Larinier et al., 2005).

In conclusion, our demonstration that a majority of the upstream migrating salmon in this river stock had problems to bypass the existing hydropower complex in their search for natural spawning areas upriver is in conflict with sustainable management of the anadromous fish resources. If these problems are not taken into account and solved, we will compromise the future of the salmon population for the generations to come.

Acknowledgments Thanks to Elforsk, the Swedish Energy Agency, the National Board of Fisheries, the Swedish Environmental Protection Agency and Vattenfall AB who financed this study as a part of a Swedish R\&D programme. Bo-Sören Wiklund is thanked for his never-failing support and technical skills. Johan Östergren, Nils-Erik and Björn Sjöström, and the staff at the Norrfors hatchery are thanked for their co-operation. Without the kind help of Vattenfall AB, this study could not have been undertaken. The National Board of Fisheries in Luleå financed the Carlin taggings. This study was carried out under licence from the Swedish Animal Welfare Agency (CFN Dnr. A70-03 and A90-03).

Open Access This article is distributed under the terms of the Creative Commons Attribution Noncommercial License which permits any noncommercial use, distribution, and reproduction in any medium, provided the original author(s) and source are credited.

\section{References}

Arnekleiv, J. O. \& M. Kraabøl, 1996. Migratory behaviour of adult fast-growing brown trout (Salmo trutta, L.) in relation to water flow in a regulated Norwegian river. Regulated rivers: Research and Management 12: 39-49. 
Balk, H. \& T. Lindem, 2004. Sonar4 and Sonar 5-Pro, Post Processing System, Operator Manual v5.9.3. Lindem Data acquisition. Norway.

Banks, J. W., 1969. A review of the literature on the upstream migration of adult salmonids. Journal of Fish Biology 1: 85-136.

Bengtsson, B.-E., C. Hill, Å. Bergman, I. Brandt, N. Johansson, C. Magnhagen, A. Södergren \& J. Thulin, 1999. Reproductive disturbances in Baltic fish: a synopsis of the FiRe Project. AMBIO. Special Issue 28(1): 2-8.

Bjornn, T. C. \& C. A. Peery, 1992. A review of literature related to movements of adult salmon and steelhead past dams and through reservoirs in the lower Snake river. Moscow, Idaho, USA: US Army Corps of Engineers, Walla Walla District and Idaho Cooperative Fish and Wildlife Research Unit, Draft Technical Report 92-1, $107 \mathrm{pp}$.

Byström, C., 1867. Om fisket i Umeå elf och skärgård, Lantbruksakademiens Tidskrift, December 1867, Berättelse 20: 91-100 (In Swedish).

Calles, E. O. \& L. A. Greenberg, 2005. Evaluation of naturallike fishways for re-establishing connectivity in fragmented salmonid populations in the River Emån. River Research and Applications 21: 951-960.

Clay, C. H., 1995. Design of Fishways and Other Fish Facilities, 2nd edn. Lewis Publishers, CRC Press, Inc., Boca Raton, Florida.

Coutant, C. C. \& R. R. Whitney, 2000. Fish behavior in relation to passage through hydropower turbines: a review. Transactions of the American Fisheries Society 129: 351380.

Eriksson, T. \& L.-O. Eriksson, 1993. The status of wild and hatchery propagated Swedish salmon stocks after 40 years of hatchery releases in the Baltic rivers. Fisheries Research 18: 147-159.

Ferguson, J. W., J. G. Williams \& E. Meyer, 2002. Recommendations for improving fish passage at the Stornorrfors Power Station on the Umeälven, Umeå, Sweden. U.S. Department of Commerce, National Marine Fisheries Service, Northwest Fisheries Science Center, Seattle, Washington, February 2002.

Gowans, A. R. D., J. D. Armstrong \& I. G. Priede, 1999. Movements of Atlantic salmon in relation to a hydroelectric dam and fish ladder. Journal of Fish Biology 54: 713-726.

Gowans, A. R. D., J. D. Armstrong, I. G. Priede \& S. Mckelvey, 2003. Movements of Atlantic salmon migrating upstream through a fish-pass complex in Scotland. Ecology of Freshwater Fish 12: 177-189.

ICES, 2001. Report of the Baltic salmon and trout assessment working group. Pärnu, Estonia 28 March-6 April 2001. International Council for the Exploration of the Sea, CM 2001/ACFM, 14.

ICES, 2005. Report of the Baltic salmon and trout working group (WGBAST). Helsinki, Finland, 5-14 April 2005. International Council for the Exploration of the Sea, CM 2005/ACFM, 18.

Jensen, A. J., T. G. Heggberget \& B. O. Johnsen, 1986. Upstream migration of adult Atlantic salmon, Salmo salar L., in the River Vefsna, northern Norway. Journal of Fish Biology 29: 459-465.
Karppinen, P., T. S. Mäkinen, J. Erkinaro, V. V. Kostin, R. V. Sadkovskij, A. I. Lupadin \& M. Kaukoranta, 2002. Migratory and route-seeking behaviour of ascending Atlantic salmon in the regulated River Tuloma. Hydrobiologia 483: 23-30.

Katopodis, C., 1990. Advancing the art of engineering fishways for upstream migrants. In Proceedings of the International Symposium on Fishways, 90 in Gifu, Japan, October 810, 1990: 19-28.

Laine, A., 1995. Fish swimming behaviour in Finnish fishways. In Komura, S. (ed.), Proceedings of the International Symposium on Fishways '95 in Gifu, Japan, October 2426, 1995. Gifu: Organising Committee for International Symposium on Fishways ' 95 in Gifu, 323-328.

Larinier, M., 1998. Upstream and downstream fish passage experience in France. In: Jungwirth, M., S. Schmutz \& S. Weiss (eds), Fish Migration and Fish Bypasses. Cambridge University Press, Fishing News Book, 127-145.

Larinier, M., 2002a. Biological factors to be taken into account in the design of fishways, the concept of obstruction to upstream migration. Bulletin Français de la Pêche et de la Pisciculture 364(suppl.): 28-38.

Larinier, M., 2002b. Pool fishways, pre-barrages and natural bypass channels. Bulletin Français de la Pêche et de la Pisciculture 364(suppl.): 54-82.

Larinier, M., M. Chanseau, F. Bau \& O. Croze, 2005. The use of radiotelemetry for optimizing fish pass design. In Spedicato, M. T., G. Lembo \& G. Marmulla (eds), Aquatic Telemetry: Advances and Applications. FAO/ COISPA, Rome: 53-60.

Leonardsson, K., Y. Belyaev, P. Rivinoja \& H. Lundqvist, 2005. Modelling upstream migration of Atlantic salmon as a function of environmental variables. In Rivinoja, P. (ed.), Migration Problems of Atlantic Salmon (Salmo salar L.) in Flow Regulated Rivers, Chapter III, Doctoral thesis 2005:114. ISSN: 1652-6880. ISBN: 91-576-6913-9. Department of Aquaculture, Swedish University of Agricultural Science, Umeå, Sweden.

Lilja, J., 2004. Assessment of fish migration in rivers by horizontal echo sounding: problems concerning side-aspect target strength, Doctoral thesis. ISBN 951-39-1725-8. University of Jyväskylä, Finland.

Lundqvist, H., S. McKinnell, H. Fängstam \& I. Berglund, 1994. The effect of time, size and sex on recapture rates and yield after river release of Salmo salar smolts. Aquaculture 121: 245-257.

Lundqvist, H., J. Östergren \& S. McKinnell, 2006. Interannual variation in distance of spawning migration of radio tagged wild Atlantic salmon (Salmo salar) females. In Östergren, J. (ed.), Migration and genetic structure of anadromous Salmo salar \& Salmo trutta in northern Swedish rivers, Chapter 2, Doctoral thesis 2006:112. ISSN: 1652-6880. ISBN: 91-576-7261-X. Department of Aquaculture, Swedish University of Agricultural Science, Umeå, Sweden.

McKinnell, S., H. Lundqvist \& H. Johansson, 1994. Biological characteristics of the upstream migration of naturally and hatchery-reared Baltic salmon, Salmo salar L. Aquaculture and Fisheries Management 25: 45-63.

Mills, D. H., 1989. Ecology and Management of Atlantic Salmon. Chapman \& Hall, London, 351 pp. 
Montén, E., 1985. Fish and Turbines; Fish Injuries During Passage Through Power Station Turbines. Vattenfall, AB, Stockholm, Sweden.

Nilsson, C., F. Lepori, B. Malmqvist, E. Törnlund, N. Hjerdt, J. M. Helfield, D. Palm, J. Östergren, R. Jansson, E. Brännäs \& H. Lundqvist, 2005. Forecasting environmental responses to restoration of rivers used as log floatways: an interdisciplinary challenge. Ecosystems 8: 779-800.

Northcote, T. G., 1998. Migratory behaviour of fish and its significance to movement through riverine fish passage facilities. In: Jungwirth, M., S. Schmutz \& S. Weiss (eds), Fish Migration and Fish Bypasses. Cambridge University Press, Fishing News Book, 3-18.

NRC, 1996. Upstream: salmon and society in the Pacific Northwest. Report of the committee on protection and management Pacific Northwest anadromous salmonids. National Academy Press, Washington D.C.

Power, J. H. \& J. D. McCleave, 1980. Riverine movements of hatchery-reared Atlantic salmon (Salmo salar) upon return as adults. Environmental Biology of Fishes 5: 3-13.

Quinn, T. P., S. Hodgson \& C. Peven, 1997. Temperature, flow, and the migration of adult sockeye salmon (Oncorhynchus nerka) in the Columbia River. Canadian Journal of Fisheries and Aquatic Sciences 54: 1349-1360.

Rivinoja, P., 2005. Migration Problems of Atlantic Salmon (Salmo salar L.) in Flow Regulated Rivers. Doctoral thesis 2005:114. ISSN: 1652-6880. ISBN: 91-576-6913-9. Department of Aquaculture, Swedish University of Agricultural Science, Umeå, Sweden.

Rivinoja, P., K. Leonardsson \& H. Lundqvist, 2005. Size dependent power-station induced mortality of smolts (Salmo sp.) and the potential effects on the spawning stock. In Rivinoja, P. (ed.), Migration Problems of Atlantic Salmon (Salmo salar L.) in Flow Regulated Rivers, Chapter VI. Doctoral thesis 2005:114. ISSN: 1652-6880. ISBN: 91-576-6913-9. Department of Aquaculture, Swedish University of Agricultural Science, Umeå, Sweden.
Rivinoja, P., S. McKinnell \& H. Lundqvist, 2001. Hindrances to upstream migration of Atlantic salmon (Salmo salar) in a northern Swedish river caused by a hydroelectric powerstation. Regulated Rivers: Research and Management 17: 101-115.

Rivinoja, P., K. Leonardsson \& H. Lundqvist, 2006. Migration success and migration time of gastrically radio-tagged $\mathrm{v}$. PIT-tagged adult Atlantic salmon. Journal of Fish Biology 69: 304-311. DOI:10.1111/j.1095-8649.2006.01101.x

Scruton D. A., R. S. McKinley, N. Kouwen, W. Eddy \& R. K. Booth, 2002. Use of telemetry and hydraulic modeling to evaluate and improve fish guidance efficiency at a louver and bypass system for downstream-migrating Atlantic salmon (Salmo salar) smolts and kelts. Hydrobiologia 483: 83-94.

Thorstad, E. B., F. Økland, F. Kroglund \& N. Jepsen, 2003. Upstream migration of Atlantic salmon at a power station on the River Nidelva, Southern Norway. Fisheries Management and Ecology 10: 139-146.

Trépanier. S., M. A. Rodríguez \& P. Magnan, 1996. Spawning migrations in landlocked Atlantic salmon: Time series modeling of river discharge and water temperature effects. Journal of Fish Biology 48: 925-936.

Vasemägi, A., R. Gross, T. Paaver, M. L. Koljonen \& J. Nilsson, 2005. Extensive immigration from compensatory hatchery releases into wild Atlantic salmon population in the Baltic sea: spatio-temporal analysis over 18 years. Heredity 95: 76-83.

Webb, J., 1990. The movements of adult Atlantic salmon in the River Tay and Tummel to Pitlochry Dam. Scottish Fisheries Research Report 48: 27 pp.

Williams, J. G., 1998. Fish passage in the Columbia River, USA and its tributaries: problems and solutions. In Jungwirth, M., S. Schmutz \& S. Weiss (eds), Fish Migration and Fish Bypasses. Fishing News Book, University Press, Cambridge: 180-191. 